\title{
Сверхбыстрая динамика электронно-дырочной плазмы в полупроводниковых нитевидных нанокристаллах *
}

\author{
(C) В.Н. Трухин ${ }^{1}$, А.Д. Буравлев ${ }^{3}$, И.А. Мустафинн ${ }^{1,2}$, Г.Э. Цырлин ${ }^{3}$, J.P. Kakko ${ }^{4}$, H. Lipsanen $^{4}$ \\ ${ }^{1}$ Физико-технический институт им. А.Ф. Иоффе Российской академии наук, \\ 194021 Санкт-Петербург, Россия \\ ${ }^{2}$ Национальный исследовательский университет ИТМО, \\ 197101 Санкт-Петербург, Россия \\ ${ }^{3}$ СПбАУ НОЦНТ Российской академии наук, \\ 194021 Санкт-Петербург, Россия \\ ${ }^{4}$ Department of Electronics and Nanoengineering, Aalto University, \\ FIN-02150 Espoo, Finland \\ E-mail: valera.truchin@mail.ioffe.ru
}

(Получена 27 апреля 2017 г. Принята к печати 12 мая 2017 г.)

Представлены экспериментальные результаты исследования влияния электронно-дырочной плазмы на генерацию ТГц-излучения в полупроводниковых нитевидных нанокристаллах на основе GaAs, выращенных методами MOVPE. Было показано, что временна́я динамика фотовозбужденных носителей заряда в полупроводниковых нитевидных нанокристаллах определяется транспортом носителей заряда, как электронов, так и дырок, временем захвата электронов и дырок на поверхностные уровни.

DOI: $10.21883 /$ FTP.2017.12.45177.40

* Полный текст этой статьи будет опубликован в журнале „Физика и техника полупроводников“, том 52 вып. 1. 